\title{
KONSEP KESEJAJARAN GARIS DALAM GEOMETRI EUCLID DAN GEOMETRI RIEMANN SERTA APLIKASINYA DALAM KAJIAN ILMU FALAK
}

\author{
Agus Solikin \\ Prodi Ilmu Falak Fakultas Syariah dan Hukum, \\ Universitas Islam Negeri Sunan Ampel Surabaya \\ agussolikin2@gmail.com
}

\begin{abstract}
ABSTRAK
Kesejajaran garis dalam geometri Euclid dan Riemann dalam kajian matematika memiliki perbedaan. Perbedaan dalam konsep kesejajaran garis tersebut, tentunya akan memberikan perbedaan pada kajian-kajian berikutnya. Berdasarkan hal tersebut, maka penelitian ini dirancang untuk mengkaji berkenaan konsep kesejajaran garis dalam geometri Euclid dan Riemann, kemudian aplikasinya dalam kajian ilmu Falak Berdasarkan fokus pembahasan tersebut, maka metode penelitian direncanakan dalam bentuk deskriptif kualitatif, dengan sumber data literaturliteratur yang terkait dengan fokus penelitian dan data dikumpulkan dengan cara penelaahan dokumen-dokumen tersebut. Selanjutnya data yang terkumpul dianalisis dengan cara deskriptif analitis induktif yang menggunakan pendekatan grounded theory. Berdasarkan penelitian ini diperoleh suatu penjelasan yang utuh tentang konsep kesejajaran garis dalam geometri Euclid dan Riemann, bahwa dalam geometri Euclid dikenal kesejajaran garis, sedangkan dalam geometri Riemann tidak kenal kesejajaran garis. Berkenaan dengan aplikasi dari kesajajaran garis dalam geometri Euclid pada kajian ilmu falak dapat dilihat pada konsep dip (kerendahan ufuk), sedangkan kesejajaan garis dalam geometri Reemann pada kajian ilmu falak dapat diketemukan pada konsep lintang geografis pada suatu tempat.
\end{abstract}

Kata kunci: kesejajaran garis, geometri euclid, geometri riemann, ilmu falak

\section{ABSTRACT}

The line parallel in the geometry of Euclid and Riemann in mathematical studies has a difference. Differences in the concept of line alignment, of course, will make a difference in the next studies. Based on this, this research is designed to study the concept of line alignment in the geometry of Euclid and Riemann, then its application in the study of Falak science Based on the focus of the discussion, the research method is planned in the form of descriptive qualitative, with data source literature related to the focus research and data were collected by reviewing the documents. Further data collected were analyzed by using inductive analytical descriptive method using grounded theory approach. Based on this research we get a complete explanation of the concept of line alignment in the geometry of Euclid and Riemann, that in Euclid geometry known line alignment, whereas in Riemann geometry do not know the line alignment. With regard to the application of the line alignment in Euclid geometry in the study of astronomy can be seen in the concept of dip (lower horizon), whereas the line universe in the geometry of Reemann in the study of astronomy can be found in the concept of geographical latitude in a place.

Keywords: line alignment, euclid geometry, riemann geometry, astronomy

\section{PENDAHULUAN}

Salah satu cabang kajian matematika adalah geometri dengan focus kajiannya yaitu mempelajari bentuk atau bangun suatu objek beserta ukurannya. Diantara kajian yang ada dalam geometri yaitu terkait dengan definisi-definisi, 


\section{Agus Solikin}

postulat-postulat, aksioma-aksioma, serta dalil-dalil yang dikemukakan oleh Euclid yang kemudian lebih familiar dengan geometri Euclid.

Euclid memiliki karya buku dengan jumlah 13 buku. Buku 1-6 menjelaskan tentang geometri datar yang meliputi segitiga, segi empat, lingkaran, segi banyak, perbandingan dan kesebangunan. Buku ke 7-10 menjelaskan tentang teori bilangan, sedangkan buku ke 11 berhubungan dengan geometri ruang, buku ke 12 menjelaskan tentang limas, kerucut dan tabung, buku ke 13 menjelaskan tenatng bidang banyak (Teguh Budiarto \& Masriyah:1)

Selain geometri Euclid yang pembahasannya seperti disebutkan di atas, dalam matematika ada pula yang dikenal dengan geometri Riemann. Geometri Riemaan hadir untuk menatang tentang postulat yang ada dalam geometri Euclid. Sebagaiamana diketahui, dalam geometri Euclid ada sebuah postula kesejajaran garis, yang secara umum memberikan penjelasan bahwa ada konsep terkait dengan garis sejajar, sedangkan geometri Riemann tidak mengenal tentang konsep garis sejajar.

Fenomena perbedaan konsep yang mendasar tersebut, mendorong peneliti untuk mengkaji tentang konsep kesejajaran garis dalam geometri Euclid dan Riemann serta aplikasi dari dua konsep tersebut dalam kajian ilmu falak. Harapan yang ingin dicapai dengan penelitian ini yaitu akan diperolehnya penjelasan mengenai dua konsep tersebut secara utuh dan manfaat dua konsep terebut dalam kajian ilmu falak.

\section{METODE PENELITIAN}

1. Jenis dan Sumber data Penelitian

a) Jenis Penelitian

Menurut Suryana (2010:18) penelitian dapat dibedakan menjadi dua jenis yaitu berdasarkan sifat masalahnya dan berdasarkan tujuannya. Berdasarkan sifat masalahnya penelitian ini dirancang sebagai penelitian deskriptif yang bertujuan untuk membuat diskripsi secara sistematis, faktual dan akurat mengenai faktafakta yang ada, terkait dengan konsep tentang kesejajaran garis yang ada dalam geometri Euclid dan Riemann serta aplikasinya dalam kajian ilmu falak. 
Selaras dengan hal tersebut di atas, maka penelitian ini menurut Moleong (2004:6) termasuk dalam penelitian kualitatif, karena memiliki karakteristik kemungkinan data yang dikumpulkan adalah kata-kata bukan angka-angka.

Berdasarkan hal tersebut, maka penelitian ini dirancang termasuk ke dalam jenis penelitian diskriptif kualitatif.

b) Sumber Data Penelitian

Moleong (2004:157) menyebutkan sumber data utama dalam penelitian kualitatif adalah kata-kata dan tindakan. Berkaitan dengan hal itu, maka katakata yang dimaksud dalam penelitian ini, yaitu kata-kata yang diperoleh dari sumber-sumber tertulis.

Secara terperinci, sumber data dalam penelitian ini ada tiga yaitu sumber data primer, sumber data skunder, dan sumber data tersier. Sumber data primer dalam penelitian ini yaitu buku yang membahas tentang geometri Euclid dan Riemann serta aplikasinya dalam kajian ilmu falak.

Sumber data skunder dalam penelitian ini adalah karya-karya lain yang langsung berkaitan atau tidak berkaitan dengan objek penelitian. Sedangkan sumber data tersier dalam penelitian ini yaitu karya-karya lain yang ada relevansi dengan objek penelitian yaitu geometri Euclid dan Riemann serta aplikasinya dalam kajian ilmu falak.

\section{Metode Pengumpulan Data}

Metode pengumpulan data pada penelitian ini yaitu dengan dokumentasi penelaahan dokumen-dokumen yang terkait dengan obyek penelitian, penelaahan dokumen dilakukan dengan secermat mungkin dan diupayakan diambil dari sumber dokumen aslinya.

\section{Metode Analisis Data}

Data yang diperoleh diklasifikasikan ke dalam data utama dan data pendukung. Kemudian data di analisis dengan menggunakan metode deskriptif analitis induktif. Analisis induktif dilakukan karena, menurut Moleong (2004:10) 


\section{Agus Solikin}

dapat menemukan kenyataan secara keseluruhan seperti yang terdapat dalam data. Selain itu, pendekatan yang digunakan untuk menganalisis data yaitu pendekatan grounded theory.

Hal mendasar dari pendekatan grounded theory yaitu sebuah teori harus disusun dari bawah dengan menggunakan seperangkat prosedur yang sistematik, kemudian di analisis dengan cara induktif untuk mendapatkan hasil tentang hubungan teori-teori tersebut (Moleong,2004:26-30).

Pendekatan grounded theory dalam penelitian ini untuk menganalisis datadata yang diperoleh berkenaan dengan geometri Euclid dan Riemann serta aplikasinya dalam kajian ilmu falak.

\section{Analisis Konsep Kesejajaran}

\section{Konsep Kesejajaran Euclid}

Konsep kesejajaran euclid pada bagian ini berangkat dari postulat kesejajaan Euclid berbunyi

"Jika dua garis dipotong oleh sebuah garis transversal sedemikian hingga membuat jumlah sudut dalam sepihak kurang dari $180^{\circ}$, maka kedua garis itu berpotongan pada pihak yang jumlah sudut dalam sepihaknya kurang dari $180^{\circ \prime}$.

Postulat kesajajaran tersebut mungkin akan terkesan susah untuk dipahami, sehingga perlu disederhanakan dalam bentuk gambar yaitu sebagai berikut:

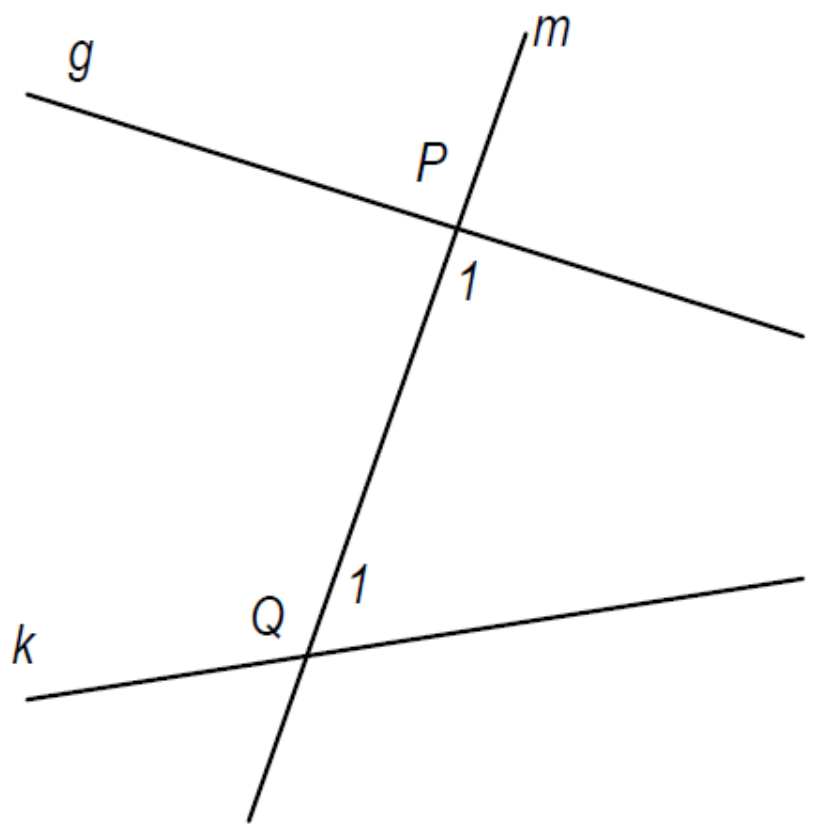


Guna mempermudah pemahaman maka, postulat tersebut dibagi dalam dua bagian yaitu Jika dua garis dipotong oleh sebuah garis transversal sedemikian hingga membuat jumlah sudut dalam sepihak kurang dari $180^{\circ}$. dan bagian kedua yaitu maka kedua garis itu berpotongan pada pihak yang jumlah sudut dalam sepihaknya kurang dari $180^{\circ}$.

Bagian pertama dua garis dipotong oleh sebuah garis transversal sedemikian hingga membuat jumlah sudut dalam sepihak kurang dari $180^{\circ}$ dapat dipahami dengan langkah

a. Pandang garis $\mathrm{m}$, garis $\mathrm{m}$ merupakan garis lurus yang memotong garis $\mathrm{k}$ dan $\mathrm{g}$, di titik $\mathrm{P}$ dan $\mathrm{Q}$.

b. Sudut P1 dan Q1 besarnya kurang dari $90^{\circ}$, sehingga P1 dan Q1 jika dijumlahkan besarnya kurang dari $180^{\circ}$.

c. Posisi sudut P1 dan Q1 adalah sudut dalam sepihak.

Tiga langkah ini yang selanjutnya akan digunakan untuk memahami postulat kejajaran euclid yang kedua yaitu kedua yaitu garis itu berpotongan pada pihak yang jumlah sudut dalam sepihaknya kurang dari $180^{\circ}$. Guna memahami bagian kedua ini maka kembali lihat gambar berikut:

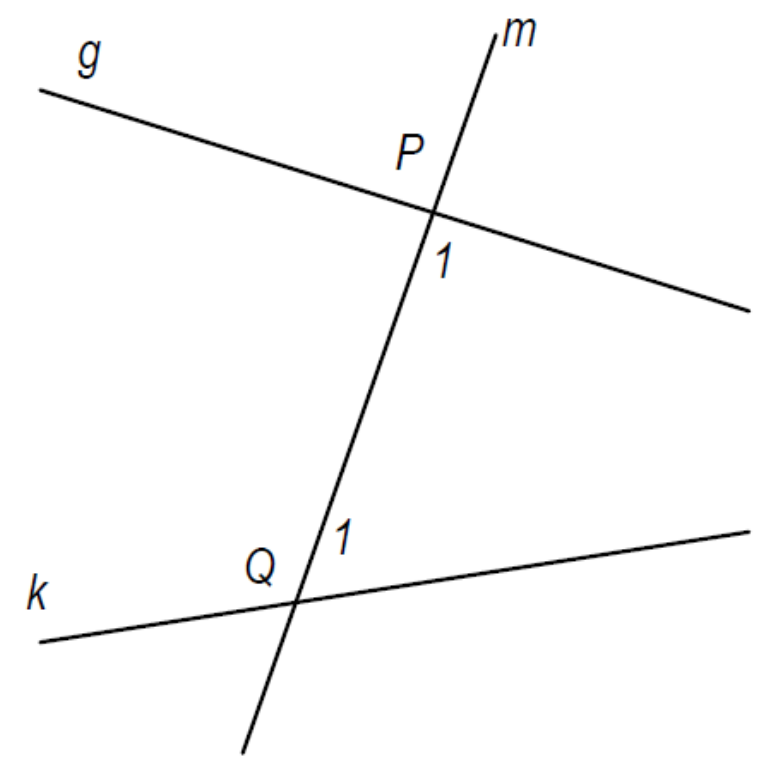

berdasarkan gambar tersebut maka lakukanlah kegiatan berikut:

a. perpanjanglah garis $\mathrm{g}$ dan $\mathrm{k}$ 
b. setelah diperpanjang maka, garis $\mathrm{g}$ dan $\mathrm{k}$ akan bertemu atau berpotongan disebelah kanan garis $m$ yang tak lain adalah berada pada pihak yang sama dengan sudut P1 dan Q1.

Selanjutnya, jika tiga lankah pada bagian pertama dan dua langkah pada bagian kedua digabungkan,maka postulat kesejajaran Euclid akan terbukti. Guna menambah pemahaman lebih lanjut, perhatikan gambar berikut dan ikuti langkahlangkah selanjutnya:

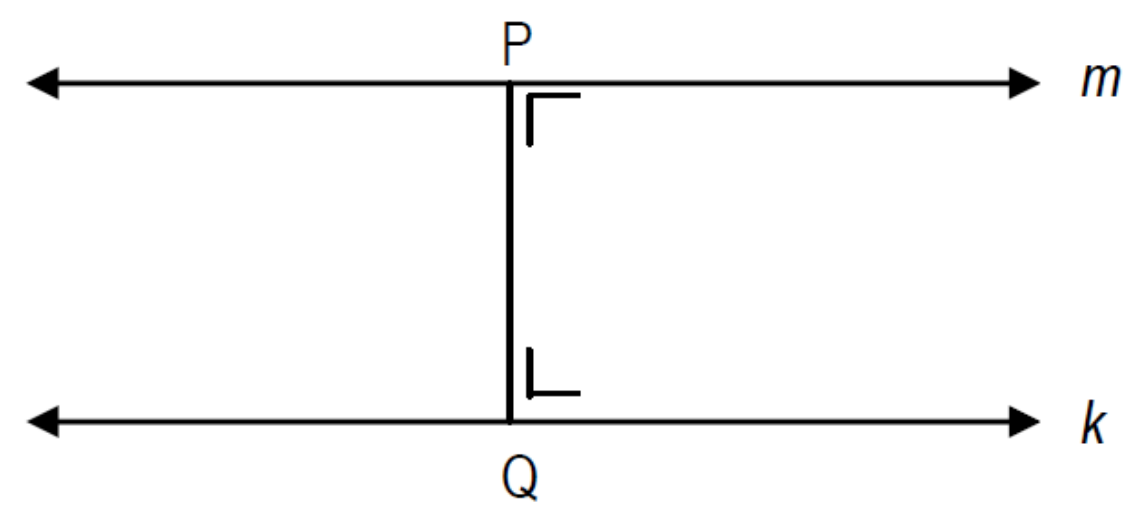

a. Pandang garis $\mathrm{p}$, garis $\mathrm{p}$ merupakan garis lurus yang memotong garis $\mathrm{k} \mathrm{dan} \mathrm{m}$, di titik P dan Q.

b. Sudut P1 dan Q1 besarnya $90^{\circ}$, sehingga P1 dan Q1 jika dijumlahkan besarnya $180^{0}$

c. Posisi sudut P1 dan Q1 adalah sudut dalam sepihak.

d. perpanjanglah garis $\mathrm{g}$ dan $\mathrm{k}$

e. setelah diperpanjang maka, garis $\mathrm{g}$ dan $\mathrm{k}$ tak akan bertemu atau berpotongan dikarenakan garis $\mathrm{k}$ dan $\mathrm{m}$ adalah dua garis yang sejajar.

Uraian di atas-menunjukkan bahwa postulat yang disampaikan oleh Eucllid, pada hakikatnya yaitu ingin memberikan pengertian tentang garis sejajar, akibat dari postulat euclid ini akhirnya dapat diketemukan bahwa dua garis yang tegak lurus pada garis yang sama maka dua garis tersebut adalah sejajar. Sebagaimana dalam gambar bahwa garis $\mathrm{m}$ dan $\mathrm{k}$ tegak lurus terhadap garis $\mathrm{PQ}$ maka garis $\mathrm{m}$ dan $\mathrm{k}$ adalah sejajar. 


\section{Konsep Kesejajan Riemann}

Geomertri Riemann lahir dengan latar belakang postulat kesejajaran euclid, dimana para ahli matematika banyak yang mempertanyakan tentang postulat tersebut diantaranya Riemann. Riemann terkait dengan kesejajaran garis mengatakan bahwa tidak ada garis yang sejajar.

Terkait dengan pernyataan riemann tersebut, maka untuk mempermudah pemahaman perhatikan dan ikuti langkah-langkahnya.

a. Ambil sebuah bola dan sebuah spidol

b. Buatlah sebuah lingkaran dengan titik pusat lingkaran berada di titik pusat bola (seperti gambar lingkaran L pada gambar berikut ini).

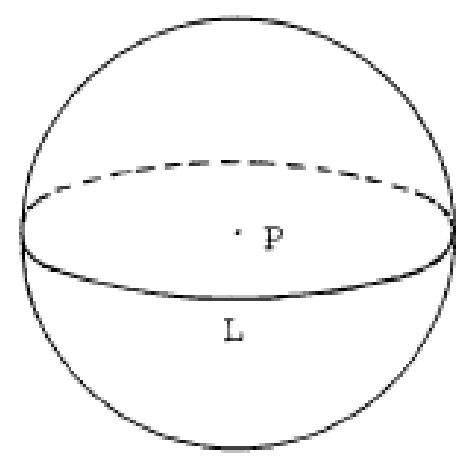

c. Bayangkan ada sebuah garis $\mathrm{K}$ yang tegak lurus dengan lingkaran L yang melalui titik pusat bola dan memeotong permukaan bola di dua tempat berbeda (lihat gambar berikut)

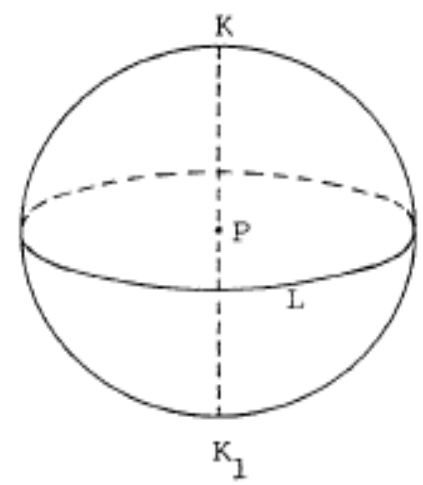

d. Ambil dua buah titik yang berbeda pada lingkaran L. Hubungkan masingmasing dua buah titik tersebut ke titk kutub 


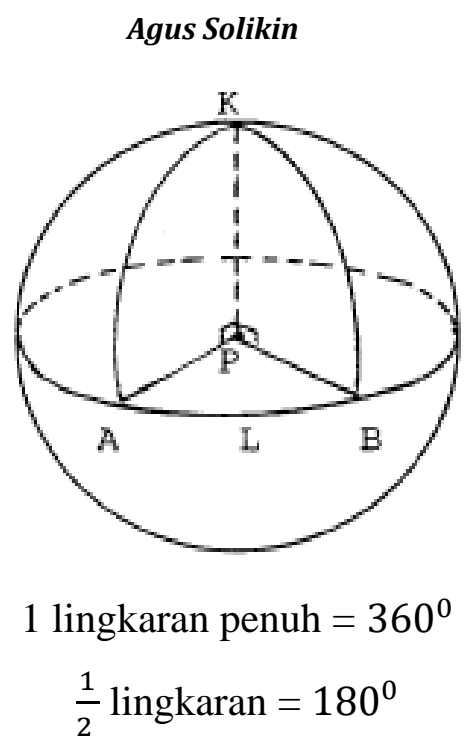

Sehingga, Jarak titik A ke kutub K yaitu $90^{\circ}$

Jarak titik B ke kutub K yaitu $90^{\circ}$

Kesimpulan:

Jarak A = Jarak B

Jika A dan B adalah dua garis yang tegak lurus ( besar sudutnya $90^{\circ}$ ) terhadap garis yang sama, maka menurut euclid seharusnya A dan B sejajar. Jika A dan B sejajar maka akibat berikutnya dua garis tersebut tak akan bertemu atau berpotongan. Namun, lihat gambar di atas, Titik A dan B beretemu pada sebuah titik yaitu titik $\mathrm{K}$, sehingga A dan B menurut Rieemann tidaklah sejajar.

\section{Kerendahan Ufuk Dan Lintang Dalam Kajian Ilmu Falak}

1. Kerendahan Ufuk

Kerendahan ufuk ialah perbedaan kedudukan antara ufuk yang sebenarnya (hakiki) dengan ufuk terlihat (mar'i) oleh seorang pengamat. Dalam astronomi disebut Dip dan dalam dunia falak biasa diistilahkan dengan ikhtil $\pm f$ al-uf-q. Dip terjadi karena ketinggian tempat pengamatan mempengaruhi ufuk (horizon). Horizon yang teramati pada ketinggian mata sama dengan ketinggian permukaan laut disebut horizon benar (true horizon) atau ufuk hissi. Ufuk ini sejajar dengan ufuk hakiki yang bidangnya melalui titik pusat bumi. Horizon yang teramati oleh mata pada ketinggian tertentu diatas permukaan laut, disebut horizon semu atau 
ufuk mar'i. Rumus pendekatan untuk menghitung sudut Dip adalah sebagai berikut:

$$
\begin{aligned}
\text { Dip }= & 1,76 \text { Öm } \\
\mathrm{m}= & \text { Ketinggian tempat dari permukaan laut dari daerah sekitar (markaz) } \\
& \text { Data ini diperlukan untuk menghitung ketinggian matahari pada } \\
& \text { saat terbenam dan terbit }
\end{aligned}
$$

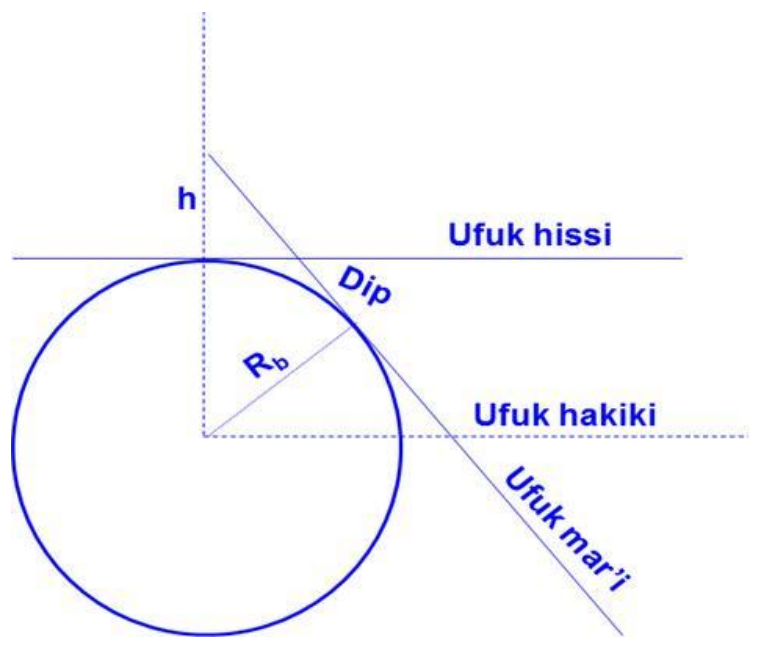

\section{Lintang}

Penetapan lintang dan bujur berbagai tempat di dunia ini didasarkan hasil kongres internasional yang dihadiri oleh 25 negara. Kongres itu berlangsung tanggal 1 sampai 22 Oktober 1884. Dalam menetapkan meridian nol di bumi, tidak ada kesepakatan. Amerika, Inggris, Turki dan sebagian negara lain sepakat bahwa titik pangkal mulai menghitung meridian itu adalah Greenwich, sebuah tempat di selatan kota London. Sedang Prancis menginginkannya di kota Paris, sementara 2 negara abstain. Meridian lain dinyatakan dengan derajat yang dihitung dari meridian Greenwich, yakni dari $0^{\circ}-180^{\circ}$ ke arah Timur disebut BT dan $0^{\circ}-180^{\circ}$ ke arah Barat disebut BB

Lintang tempat adalah jarak suatu tempat dari khatulistiwa/equator bumi diukur sepanjang garis bujur yang melalui tempat itu. Lintang tempat itu positif $(+)$, bila tempat itu berada pada belahan bumi bagian Utara, terhitung dari $0^{\circ}$ di equator bumi sampai $90^{\circ}$ di kutub bumi Utara. Dan negatif $(-)$, bila tempat itu berada di belahan bumi bagian Selatan, terhitung dari $0^{\circ}$ di equator bumi sampai 


\section{Agus Solikin}

$90^{\circ}$ di kutub bumi Selatan. Dalam I. Falak, lintang tempat ini disebut Phi (Yunani) dan diberi kode $(\varphi)$.

Informasi tentang lintang tempat ini bisa dilihat misalnya dalam Atlas PR. Bos, software komputer yang telah banyak beredar.

Bujur Tempat adalah jarak suatu tempat ke garis bujur yang melalui kota Greenwich di selatan kota London.Berbagai tempat di bumi ditentukan bujurnya melalui posisinya dari titik $0^{\circ}$ di kota Greenwich sampai $180^{\circ}$, baik ke arah Barat (BB) maupun ke arah Timur (BT). Bujur $180^{\circ}$ Barat berhimpit dengan bujur $180^{\circ}$ Timur di lautan Pasifik dan dijadikan garis batas tanggal internasional (International Date Line).

Dalam ilmu Falak, bujur tempat ini disebut Lambda dan diberi kode $(\lambda)$. Seperti halnya lintang tempat, maka daftar bujur tempat inipun bisa dilihat dalam berbagai buku atau software komputer.

\section{Aplikasi Konsep Kesejajaran Dalam Kerendahan Ufuk Dan Lintang}

1. Aplikasi Konsep Kesejajaran Euclid Dalam Kerendahan Ufuk.

Sebagaimana diketahui pada penjelasan sebelumnya, bahwa kerendahan ufuk atau dip merupakan sudut yang terbentuk oleh ufuk mar'i dan ufuk hakiki, berdasarkan gambar berikut terlihat bahwa ufuk hakiki dan ufuk hissi sejajar, maka besar sudut yang terbentuk oleh ufuk hakiki dan mar'i, sama dengan sudut yang terbentuk oleh ufuk hissi dan ufuk mar'i.

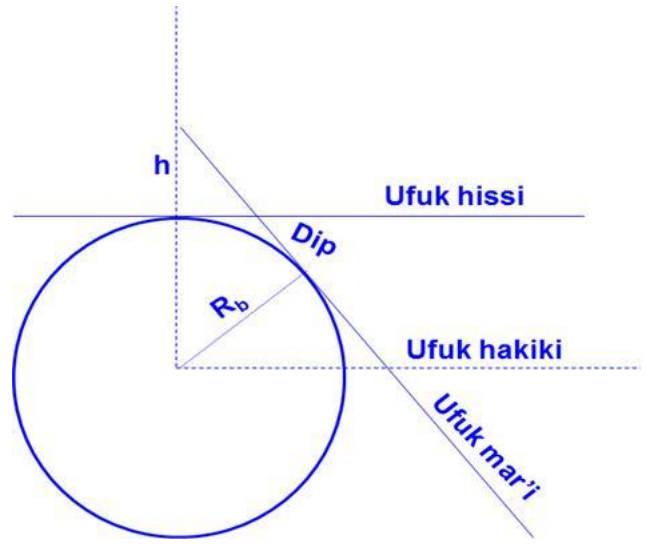

Selaras dengan penjelasan tersebut di atas, maka sebenarnya yang ada dalam pembahasan kerendahan ufuk pada kajian ilmu falak adalah aplikasi dari konsep kesjajaran Euclid, sehingga secara teori dip adalah pertemuan antara garis 
ufuk hakiki dan mar'i, namun dalam gambar tersebut dip ditaruh pada pertemuan antara garis ufuk hissi dan mar'i tidak salah, karena nilai dua sudut tersebut sama.

\section{Aplikasi Konsep Kesejajaran Riemann Dalam Lintang}

Sebagaimana dalam penjelasan sebelumnya terkait dengan lintang suatu tempat, dimana lintang suatu tempat berada antara $0^{0}-90^{0}$. Terlepas lintang utara maupun lintang selatan, menarik untuk dicermati bahwa nilai lintang suatu tempat memiliki angka maximal yaitu $90^{\circ}$ yang telah diuraikan.

Nilai maximal lintang $90^{\circ}$ tersebut jika digambarkan ke dalam globe maka seperti gamabar berikut:

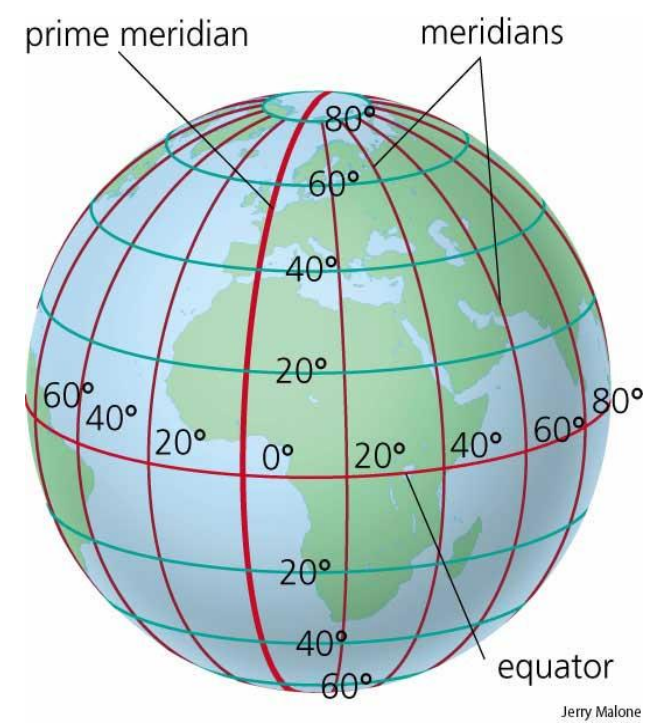

Selaras dengan gambar tersebut, maka jika ditelisik lebih jauh maka sebenarnya konsep yang ada pada lintang suatu tempat, adalah konsep kejajaran yang dikembangkan oleh Riemann.

\section{SIMPULAN}

Berdasarkan uraian dari awal hingga akhir, dapat diambil sebuah kesimpulan bahwa perkembangan tentang kesejajarn suatu garis yang di mulai oleh Euclid dan kemudian ditentang oleh Riemann menghasilkan sebuah teori yang berbeda terkait kesejajaran garis itu sendiri, namun dua teori tersebut digunakan dalam kajian ilmu falak. 
Konsep kesejajaran Euclid dapat diketemukan dalam kajian ilmu falak pada pembahasan terkait dengan kerndahan ufuk, sedangkan kesejajaran Riemann dapat diketemukan dalam pembahasan lintang suatu temapat dalam kajian ilmu falak.

\section{DAFTAR PUSTAKA}

Anugraha, R. 2012. Mekanika Benda Langit. Yogyakarta: Jurusan Fisika Fakultas MIPA Universitas Gajah Mada.

Barlow and Bryan. 1900. Elementery Mathematical Astronomy. London: W, B. Clive.

Barlow and Bryan. 1946. Elementery Mathematical Astronomy. London. University totorial press ltd.

Brenke, W. C. 1943. Plane and Spherical Trigonometry. USA: The Dryden Press.

Budiarto, T. Mega, \& Masriyah, tth. Sistem Geometri. Surabaya: Unesa University Press.

Dhillon, V. Spherical Trigonometry, Sheffield universty-UK. Spherical trigonometry. $\quad$ http://www.shef.ac.uk/uni/academi/NQ/phys/people/vdhillon/teching/phy105sphergeon.html

Hambali, S. 2011. Ilmu Falak. Semarang: Program pascasarjana IAIN Walisongo Semarang.

Moleong, L. J. 2005. Metodologi Penelitian Kualitatif. Bandung: PT Remaja Rosdakarya.

Negoro dan Harahap. 2005. Ensiklopedi Matematika. Bogor: Penerbit Ghalia Indonesia.

Purwanto, A. 2011. "Penentuan arah Kiblat". Makalah Pelatihan Hisab Falak di PWM Jatim. Tanggal 10 Juli 2011.

Purwanto, A. 2012. "Makalah Falak". Makalah Pelatihan Hisab Falak di PWM Jatim. Tanggal 17 Juli 2011.

Suryana. 2010. Metodologi Penelitian. Bogor: Universitas Pendidikan Indonesia.

Wijaya, A. 2009. Matematika Astronomi: Bagaimana Matematika Mempelajari Alam. Makalah pada Seminar Nasional MIPA di Universitas Negeri Yogyakarta. Tanggal 16 Mei 2009. 